\title{
Swab Dosage Form
}

National Cancer Institute

\section{Source}

National Cancer Institute. Swab Dosage Form. NCl Thesaurus. Code C47898.

A solid composed of a small piece of absorbent material attached to one end of a small stick. 